\title{
Pengaruh Model Pembelajaran Tutor Sebaya terhadap Hasil Belajar Siswa dalam Pembelajaran Renang Gaya Dada di Sekolah Dasar
}

\author{
Ani Kurniawati ${ }^{1}$, Arif Fajar Prasetiyo², Andi Kurniawan Pratama ${ }^{3}$, Adi Yusup \\ Supardi ${ }^{4}$ \\ Pendidikan Olahraga, Fakultas Pendidikan Islam Dan Keguruan, Universitas Garut ${ }^{1}$ \\ Pendidikan Jasmani Kesehatan dan Rekreasi Fakultas Keguruan dan Ilmu Pendidikan Universitas \\ Subang ${ }^{2}$ \\ Pendidikan Jasmani Kesehatan dan Rekreasi Fakultas Keguruan dan Ilmu Pendidikan Universitas \\ Surya Kencana ${ }^{3}$ \\ Pendidikan Jasmani Kesehatan dan Rekreasi Fakultas Pendidikan Olahraga Dan Kesehatan \\ Universitas Pendidikan Indonesia ${ }^{4}$ \\ anikurniawati@uniga.ac.id ${ }^{1}$ ariffajarprasetyo@gmail.com²andikpratama@unsur.ac.id²a.k_thasaa \\ @yahoo.co.id ${ }^{4}$
}

\begin{tabular}{|c|}
\hline bstrak \\
\hline $\begin{array}{l}\text { Model pembelajaran Peer Teaching pada dasarnya merupakan sebuah kegiatan } \\
\text { pembelajaran dengan memilih seorang siswi yang akan dijadikan guru dengan istilah "tutor", tutor } \\
\text { tersebut nantinya akan membantu siswi lain (learner) dalam mempelajari materi pelajaran atau } \\
\text { tugas gerak dalam sebuah proses pembelajaran. Model pembelajaran peer teaching berpotensi } \\
\text { menjadi salah satu model pembelajaran yang dapat digunakan untuk mengatasi beberapa } \\
\text { aspek yang menghambat dalam proses pembelajaran dan juga membantu mengatasi } \\
\text { kesulitan guru dalam mengamati dan memberikan umpak balik pada setiap. Sampel } \\
\text { penelitian adalah siswa kelas V sebanyak } 32 \text { orang siswa yang terdiri atas } 17 \text { siswa laki - } \\
\text { laki dan } 15 \text { siswa perempuan. Tujuan penelitian ini adalah untuk apakah terdapat pengaruh dari } \\
\text { penggunaan model pembelajaran tutor sebaya terhadap hasil belajar siswa dalam pembelajaran } \\
\text { renang gaya dada di sekolah dasar. Metode yang digunakan Penelitian Tindakan Kelas yang terdiri } \\
\text { dari } 2 \text { siklus. Hasil penelitian menunjukkan bahwa penggunaan model pembelajaran tutor sebaya } \\
\text { memberikan pengaruh terhadap hasil belajar siswa dalam pembelajaran renang gaya dada. } \\
\text { Berdasarkan hasil analisis data menyimpulkan adanya pengaruh dalam hal peningkatan persentase } \\
\text { ketuntasan yakni pada siklus I yaitu dengan nilai rata-rata nilai } 64 \text { dengan presentase ketuntasan } \\
\text { 25\% dan pada siklus II nilai rata-rata nilai } 78 \text { dengan presentase ketuntasan } 81 \% \text {. Kesimpulan } \\
\text { penelitian penggunaan model pembelajaran tutor sebaya terhadap hasil belajar siswa dalam } \\
\text { pembelajaran renang gaya dada di sekolah dasar. }\end{array}$ \\
\hline Kata Kunci: Gaya Dada; Hasil belajar; Renang; Tutor Sebaya \\
\hline Abstract \\
\hline $\begin{array}{l}\text { The Peer Teaching learning model is basically a learning activity by choosing a student who will } \\
\text { be a teacher with the term "tutor", the tutor will later help other students (learners) in studying } \\
\text { subject matter or motion tasks in a learning process. The peer teaching learning model has } \\
\text { the potential to be one of the learning models that can be used to overcome several aspects } \\
\text { that hinder the learning process and also help overcome teacher difficulties in observing } \\
\text { and giving feedback to each } 17 \text { male students and } 15 \text { female students. The purpose of this } \\
\text { study was to determine whether there was an effect of the use of peer tutor learning models on } \\
\text { student learning outcomes in breaststroke swimming lessons in elementary schools. The method } \\
\text { used is Classroom Action Research which consists of } 2 \text { cycles. The results showed that the use of } \\
\text { peer tutoring learning model had an influence on student learning outcomes in breaststroke } \\
\text { swimming lessons. Based on the results of data analysis concluded that there was an influence in }\end{array}$ \\
\hline
\end{tabular}




\begin{abstract}
of 64 with a percentage of completeness of $25 \%$ and in the second cycle the average value of 78 with a percentage of completeness of $81 \%$. The conclusion of the study was the use of peer tutoring learning models on student learning outcomes in breaststroke swimming lessons in elementary
\end{abstract} schools.

Keywords: Breaststroke; Learning outcomes; Peer tutors; Swimming.

Diterima (30 Agustus 2021) Disetujui (30 September 2021) Dipublikasikan (30 September 2021)

\title{
PENDAHULUAN
}

Pendidikan jasmani merupakan pendidikan melalui aktivitas fisik yang di dalamnya terdapat olahraga. Pelajaran olahraga dan kesegaran jasmani dalam sistem pendidikan dipandang penting sehingga masuk ke dalam kurikulum bidang studi wajib yang dinamakan bidang studi pendidikan jasmani dan olahraga(Jiwa, 2019), seseorang pendidik yang ahli dibidangnya bertanggungjawab untuk menyampaikan bidang studi tersebut kepada anak didiknya sehingga seseorang yang bertanggungjawab mengajar bidang studi tersebut adalah guru pendidikan jasmani (Ruiz-montero, Chiva-bartoll, \& Salvador-garc, 2019). Tujuan pendidikan jasmani seringkali didefinisikan dalam redaksi yang berbeda-beda dari setiap ahli pendidikan, namun semua tujuan tersebut pada dasarnya dapat diklasifikasikan ke dalam empat kategori tujuan yaitu : 1) Perkembangan fisik, 2) Perkembangan gerak, 3) Perkembangan mental, dan 4) Perkembangan sosial. Pendidikan Jasmani.

Pendidikan jasmani merupakan salah satu bidang studi yang diajarkan di sekolah dasar (Jatmika, Hariono, Purwanto, \& Setiawan, 2017). Bidang studi pendidikan jasmani diajarkan mulai dari kelas satu sampai dengan kelas enam sekolah dasar. Pokok-pokok bahasan bidang studi pendidikan jasmani yang disampaikan terdiri dari enam pokok bahasan (Lekarskie et al., 2020), yaitu: pokok bahasan tentang atletik, pokok bahasan tentang senam, pokok bahasan tentang olahraga permainan, pokok bahasan renang, teori kesehatan dan pendidikan luar sekolah atau alam bebas. Dari keenam pokok bahasan, lima pokok bahasan, seperti atletik, senam, olahraga permainan, teori kesehatan dan pendidikan luar sekolah dapat dilaksanakan tanpa banyak hambatan, berbeda dengan renang yang tidak bisa terselenggara secara maksimal karena terkendala oleh masalah fasilitas kolam yang tidak dimiliki oleh sekolah(Probo Yusuf Wicaksono, 2017). Mengakibatkan pada kendalakendala yang lainnya masalah waktu, biaya, sehingga memerlukan pengelolaan khusus. Karena pokok bahasan renang tercantum dalam kurikulum. Sedangkan kendala-kendala cukup menyulitkan para guru pendidikan penjas dalam mengajarkan pokok bahasan renang hanya memberikan pelajaran renang secara teori saja, sehingga praktis para siswa sekolah dasar umumnya tidak mempunyai keterampilan renang secara praktik (Casey \& Quennerstedt, 2020).

Dari sisi lain aktivitas berenang yang dilakukan yang seharusnya melakukan proses pembelajaran, seakan-akan hanya melakukan aktivitas pengenalan air dengan penggunaan model pembelajaran direct instruction yang tentunya berpusat pada guru (Pawlowski \& Skovgaard, 2020). Kemudian terbatasnya waktu pembelajaran pada saat dikolam renang pun menjadi kendala bagi siswa karena siswa tidak mengeksplore kemampuanya secara penuh. Kecenderungan guru pendidikan jasmani, yang selalu menerapkan metode mengajar tradisional seperti gaya komando dan melakukan gerakan sesuai dengan perintah guru, merasa guru paling benar dalam proses pembelajaran pendidikan jasmani akan berpengaruh pada anak didiknya (Chróinín et al., 2018). Siswa harus melakukan sesuai 
dengan gerakan yang diperintahkan guru apabila salah maka akan memarahinya dan siswa tidak diberi kebebasan untuk melakukan gerakan-gerakan lainnya maka pengaruh yang timbul adalah rasa frustasi dan rasa tidak senang terhadap pendidikan jasmani.

Dari pemaparan di atas, dapat dipahami bahwa dengan pemilihan model pembelajaran yang tepat dalam artian sesuai dengan keadaan dan kebutuhan maka akan membantu guru serta peserta didik dalam pencapaian tujuan, dalam konteks ini yaitu tujuan dalam mencapai hasil belajar yang baik (Setiawan, Yudiana, Ugelta, Oktriani, \& Budi, 2020). Apabila model pembelajaran yang diterapkan oleh seorang guru kurang variatif, maka akan berdampak terhadap keterampilan gerak siswi yang tidak akan berkembang. Oleh karena itu, penggunaan suatu model pembelajaran dalam proses pembelajaran pendidikan jasmani sangatlah penting. Model pembelajaran pada dasarnya merupakan bentuk pembelajaran yang tergambar dari awal sampai akhir yang disajikan secara khas oleh guru. Dengan kata lain, model pembelajaran menurut merupakan bungkus atau bingkai dari penerapan suatu pendekatan, metode, dan teknik pembelajaran (Komalasari, 2011, hlm. 57).

Model pembelajaran memiliki tujuan yang sangat jelas yaitu di rancang sebagai upaya untuk membuat suasana pembelajaran yang tadinya monoton menjadi lebih menyenangkan. Menurut Joice \& Weil (dalam Isjoni, 2013, hlm. 50) menejlaskan bahwa : "Model pembelajaran adalah suatu pola atau rencana yang sudah direncanakan sedemikian rupa dan digunakan untuk menyusun kurikulum, mengatur materi pelajaran, dan memberi petunjuk kepada pengajar di kelasnya." Selain itu, model pembelajaran akan membantu seorang siswi dalam mempelajari materi pelajaran lebih optimal. Apabila model pembelajaran yang diterapkan oleh seorang guru efektif, maka akan membuat siswi mau berpartisipasi dan berinteraksi dalam proses pembelajaran, bahkan dampak dari penerapan suatu model pembelajaran akan menghasilkan siswi - siswi dengan pengetahuan yang luas, sikap yang baik dan mempunyai keterampilan gerak dalam suatu cabang olahraga.

Model pembelajaran peer teaching merupakan suatu proses pembelajaran teman sebaya atau dapat diartikan sebagai proses pembelajaran di mana seorang siswi yang memiliki pengetahuan lebih akan mengajarkan temannya yang lain (Renno Adiesta, 2017). Model pembelajaran peer teaching pada dasarnya merupakan sebuah kegiatan pembelajaran dengan memilih seorang siswi yang akan dijadikan guru dengan istilah "tutor", tutor tersebut nantinya akan membantu siswi lain (learner) dalam mempelajari materi pelajaran atau tugas gerak dalam sebuah proses pembelajaran (Toan, 2020). Model pembelajaran peer teaching mempunyai ciri khas yang unik, di mana yang akan mengajar atau menggantikan guru dalam memberikan suatu materi, yaitu seorang siswi yang memiliki pengetahuan atau skill yang lebih baik dari teman kelasnya. Peer teaching kondusif untuk mempromosikan lingkungan belajar yang positif dan menarik bagi tutor maupun learner (Jatmika et al., 2017). Dampak yang jelas dari implementasi dari peer teaching adalah pengembangan kognitif, psikososial dan keterampilan motorik. Model pembelajaran peer teaching berpotensi menjadi salah satu model pembelajaran yang dapat digunakan untuk mengatasi beberapa aspek yang menghambat dalam proses pembelajaran. Selain itu, model ini juga membantu mengatasi kesulitan guru dalam mengamati dan memberikan umpak balik pada setiap siswi (Meztler, 2000).

Dari pemaparan tersebut dapat disimpulkan bahwa penggunaan model pembelajaran yang tepat akan memberikan dampak yang positif bagi siswa dan tentunya dapat mencapai tujuan pembelajaran yang telah dicanangkan sebelumnya (Erdo, 2021). Maka tujuan penelitian ini adalah untuk menguji apakah terdapat pengaruh yang signifikan dari model pembelajaran tutor sebaya terhadap hasil belajar siswa dalam pembelajaran renang gaya dada di sekolah dasar. 


\section{METODE}

Metode yang digunakan dalam penelitian ini adalah metode Penelitian Tindakan Kelas (PTK), atau dikenal juga dengan istilah Classroom Action Research. Arikunto (2006, hlm. 3) menjelaskan bahwa : "Penelitian tindakan kelas merupakan suatu pencermatan terhadap kegiatan belajar berupa sebuah tindakan, yang sengaja dimunculkan dan terjadi dalam sebuah kelas secara bersama". Adapun tujuan menggunakan metode ini adalah karena metode ini merupakan sebuah bentuk inkuiri reflektif yang dilakukan secara kemitraan mengenai situasi sosial tertentu (termasuk pendidikan) untuk meningkatkan rasionalitas dan keaslian dari a) Kegiatan praktek sosial atau pendidikan mereka, b) Pemahaman mereka mengenai kegiatan-kegiatan praktek pendidikan ini, dan c) Situasi yang memungkinkan terlaksananya kegiatan praktek ini. (Kemmis, 1983 dalam Wiriaatmadja 2008, hlm. 12).

\section{Populasi dan Sampel}

Populasi yang digunakan dalam penelitian ini adalah seluruh siswa SDN 195 ISOLA sebanyak 211 orang siswa yang terisir. Dalam penelitian ini penulis mengambil sampel yang diambil dengan teknik sampel purposif (purposive sample). Sampel dalam penelitian ini adalah siswa kelas V sebanyak 32 orang siswa yang terdiri atas 17 siswa laki-laki dan 15 siswa perempuan. Kaitannya dengan sampel tersebut menurut Arikunto (2006, hlm. 139) menyatakan bahwa : "Sampel bertujuan dilakukan dengan cara mengambil subjek bukan didasarkan atas strata, random atau daerah tetapi didasarkan atas adanya tujuan tertentu. Teknik ini biasanya dilakukan karena beberapa pertimbangan, misalkan alasan keterbatasan waktu, tenaga dan dana sehingga tidak dapat mengambil sample yang besar dan jauh".

\section{Instrument Penelitian}

Instrumen yang digunakan pada penelitian ini yaitu:

1. Observasi pada saat pelaksanaan pembelajaran berlangsung, hal ini digunakan untuk mengetahui segala kejadian atau peristiwa selama dalam proses tindakan dan perbaikan. Dalam penelitian ini ada dua buah lembar observasi yang digunakan, pertama yaitu lembar observasi guru terhadap siswa, dan kedua yaitu lembar observasi guru penjas terhadap peneliti. Kedua lembar tersebut merupakan panduan yang telah ditentukan dan dibuat sebelum melakukan tindakan.

2. Catatan lapangan yaitu catatan yang digunakan selama kegiatan pembelajaran berlangsung yang berguna untuk mengumpulkan informasi-informasi yang penting dan menggambarkan kejadiankejadian siswa pada saat pelaksanaan tindakan.

3. Dokumentasi (foto) digunakan untuk merekam dan mengabadikan kejadian-kejadian pada saat pelaksaan tindakan berlangsung.

4. Tes keterampilan

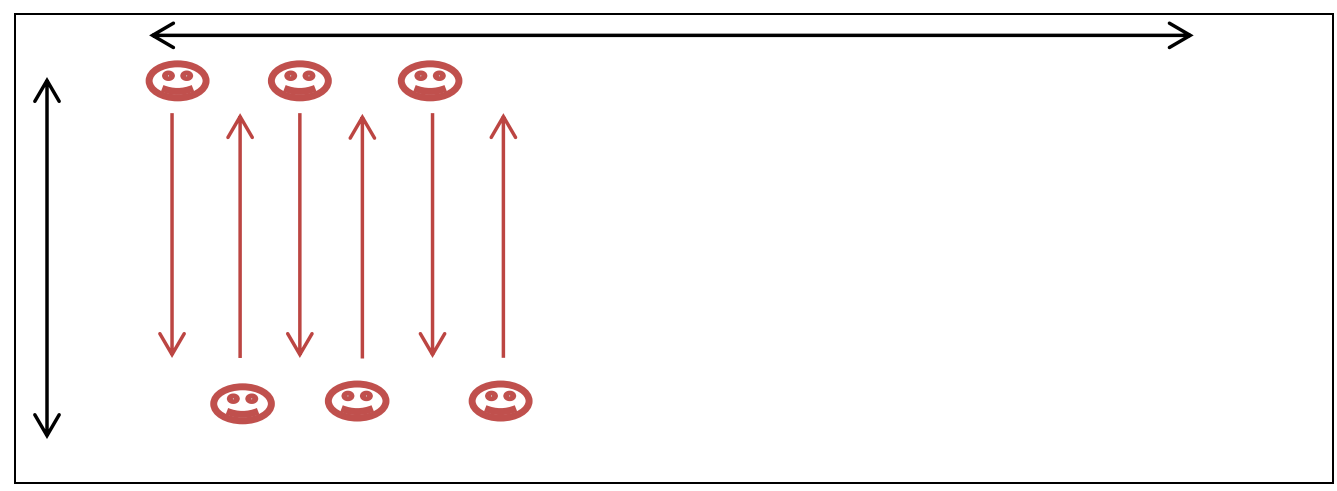


Gambar 3.2

Tes Keterampilan Renang Gaya Dada

Keterangan :

$\begin{array}{ll}\text { Siswa } & : \quad 9 \\ \text { Alur renang } & : \quad \downarrow\end{array}$

\section{Perencanaan}

Persiapan penelitian atau rencana tindakan merupakan perumusan tindakan yang tepat untuk mengawali masalah yang akan diteliti. Dalam hal ini peneliti merupakan pengajar (guru) dan di bantu oleh observer atau (guru penjas) untuk merancangkan tindakan dalam upaya meningkatkan hasil belajar renang gaya dada. Ada beberapa hal yang harus dilakukan oleh peneliti dan observer, yaitu sebagai berikut:

1. Menentukan sekolah dan kelas yang akan dijadikan tempat penelitian.

2. Meminta izin kepada sekolah yang telah dipilih sebelumnya untuk melakukan sebuah penelitian.

3. Menghubungi guru mata pelajaran Pendidikan Jasmani dan meminta kesediaanya untuk menjadi kolabolator peneliti dalam penelitian yang akan dilaksanakan.

4. Menyusun kesepakatan dengan guru mengenai waktu pelaksanaan penelitian.

5. Mendiskusikan dan menentukan metode yang akan diterapkan dan penelitian tindakan kelas.

6. Menyusun silabus dan membuat rencana pembelajaran dengan menerapkan variasi bentuk tugas gerak yang sistematis dalam pembelajaran keterampilan renang gaya dada.

7. Membuat lembar observasi, yaitu:

a. Membuat catatan lapangan yang digunakan sebagai media untuk mencatat kejadiankejadian pada saat proses pembelajaran.

b. Membuat jurnal harian yang digunakan sebagai data untuk meninjau aspek-aspek kegiatan selama berlangsungnya kegiatan pembelajaran.

c. Menggunakan media elektronik untuk mendokumentasikan fakta dan data penting pada saat pelaksanaan pembelajaran berlangsung.

8. Mempersiapkan saran dan prasarana pendukung untuk kegiatan pembelajaran renang gaya dada.

\section{Pelaksanaan Tindakan}

Langkah kedua yang perlu diperhatikan adalah langkah tindakan atau pelaksanaan yang terkontrol secara seksama. Adapun langkah-langkah peneliti dalam tindakan penelitian adalah sebagai berikut :

1. Peneliti penerapkan proses pembelajaran dengan menerapkan penggunaan alat bantu ban karet kepada siswa, sesuai dengan perencanaan pembelajaran yang telah disusun sebelumnya. 
2. Peneliti melakukan pengamatan terhadap pelaksanaan tindakan secara sadar, kritis, sistematis, dan objektif kepada seluruh siswa.

3. Peneliti mencatat segala bentuk kegiatan dan kendala yang muncul selama pembelajaran berlangsung ke dalam lembar catatan lapangan yang telah dipersiapkan.

a. Alternatif Pemecahan

Hasil dari proses pembelajaran dijadikan sebagai bahan untuk solusi yang tepat dalam melakukan tindakan perbaikan pada pembelajaran atau siklus yang akan dilakukan selanjutnya.

b. Observasi

Observasi pada PTK mempunyai fungsi untuk mendokumentasi implikasi tindakan yang diberikan kepada subjek. Oleh karena itu, observasi harus mempunyai beberapa unggulan seperti memiliki orientasi prosfektif, memiliki dasar-dasar reflektif waktu sekarang dan masa yang akan datang. Dengan begitu, pada saat proses pembelajaran sedang berlangung, peneliti harus memahami, mengamati, melihat, dan mendengar apa yang terjadi di lapangan. Dengan melakukan observasi peneliti dibantu oleh observer atau dalam hal ini guru penjas. Objek yang diamati adalah seluruh siswa yang mengikuti pembelajaran. Ada tiga fase esensial dalam observasi yaitu pertemuan perencanaan, observasi kelas, dan umpan balik.

c. Refleksi

Langkah ini merupakan sarana untuk melakukan pengkajian kembali terhadap tindakan yang telah dilakukan terhadap subjek penelitian dan telah dicatat dalam observasi. Langkah reflektif ini berusaha mencari alur pemikiran yang logis dalam kerangka kerja proses, problem, isi, dan hambatan yang muncul dalam perencanaan tindakan strategis. Hasil refleksi digunakan untuk menetapkan langkah selanjutnya dalam upaya menghasilkan perbaikan.

Tabel 3.1

Pelaksanaan Tindakan Siklus I dan Siklus II

\begin{tabular}{|c|c|c|c|}
\hline Siklus & & Tindakan & Waktu/Tanggal \\
\hline I & Perencanaan & $\begin{array}{l}\checkmark \text { Perencanaan terfokus pada } \\
\text { proses pembelajaran renang } \\
\text { gaya dada. } \\
\checkmark \text { Pemberian tugas latihan } \\
\text { renang gaya dada pada } \\
\text { siswa sesuia dengan } \\
\text { kemampuan yang } \\
\text { dimilikinya. } \\
\checkmark \text { Siswa diberi tugas } \\
\text { menggunakan ban karet } \\
\text { untuk melakukan } \\
\text { keterampilan renang gaya } \\
\text { dada. }\end{array}$ & \\
\hline
\end{tabular}




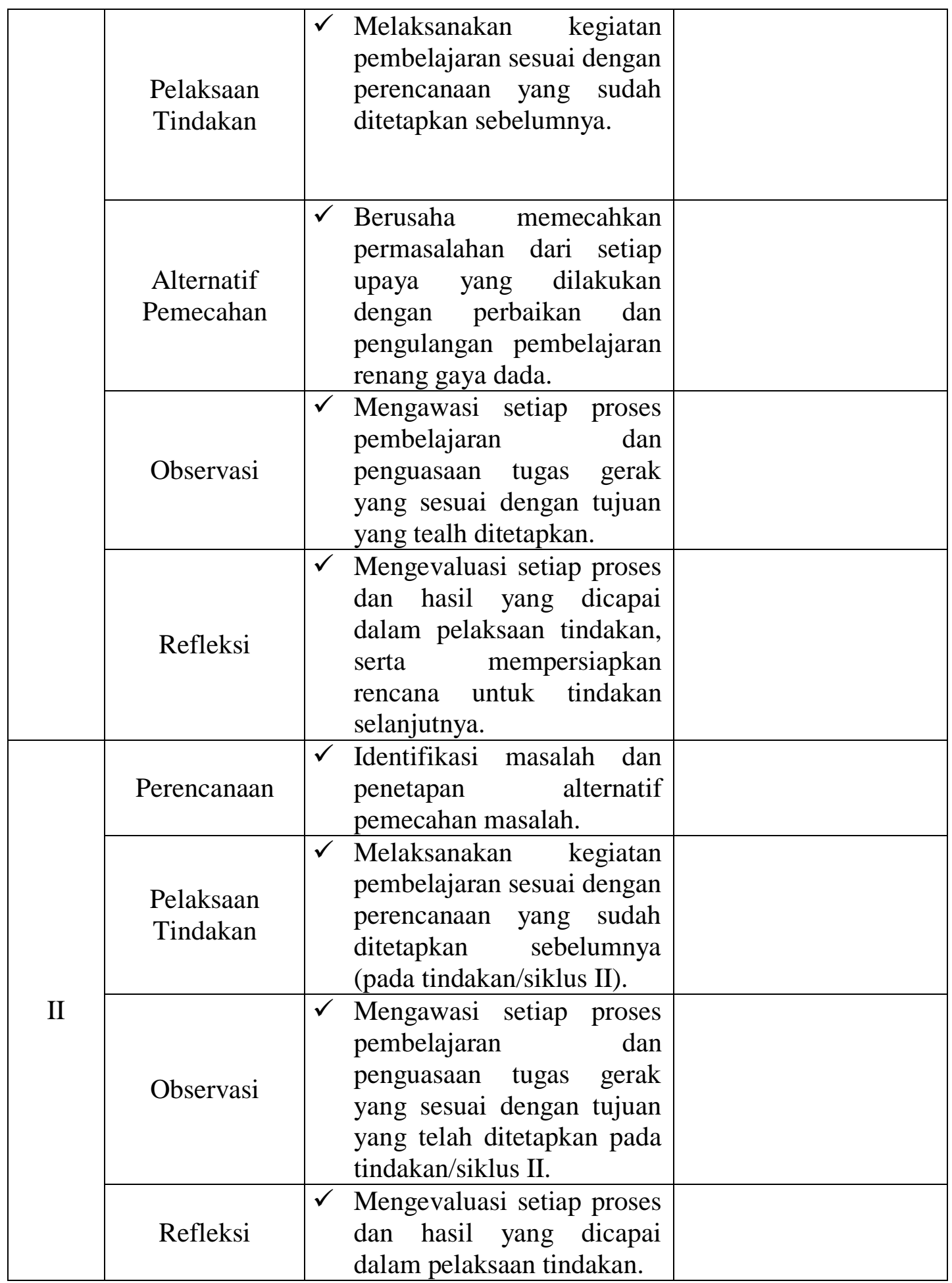

\section{Prosedur Penelitian}

Penelitian tindakan kelas ini dilakukan dalam bentuk proses berdaur (siklus). Setiap siklus terdiri dari empat tahapan (fase): perencanaan (planning), tindakan (action), pengamatan (observation), dan refleksi (reflection). Tahapan-tahapan tersebut akan dilaksanakan setelah penulis melakukan observasi awal untuk mendapatkan gambaran mengenai karakteristik kemampuan siswa 
dalam mengikuti proses pembelajaran renang. Atas dasar ini maka upaya pemecahan masalah dalam penelitian ini dilakukan dengan beberapa tindakan.

1. Perencanaan (Planning)

Pada komponen ini, guru atau peneliti merumuskan rencana tindakan yang akan dilakukan untuk memperbaiki dan meningkatkan proses pembelajaran, perilaku, sikap, dan prestasi belajar siswa.

2. Tindakan (Action)

Pasa komponen ini, guru atau peneliti melakukan tindakan berdasarkan rencana tindakan yang telah direncanakan, sebagai upaya perbaikan dan peningkatan atau perubahan prosese pembelajaran, perilaku, sikap, prestasi belajar siswa yang diinginkan.

3. Pengamatan (Observation)

Pada komponen ini, guru atau peneliti mengamati dampak atau hasil dari tindakan yang dilaksanakan atau dikenakan setiap siswa. Apakah berdasarkan tindakan yang dilakukan itu memberikan pengaruh yang meyakinkan terhadap perbaikan dan peningkatan proses pembelajaran dan hasil belajar siswa atau tidak.

4. Refleksi (Reflection)

Pada komponen ini, guru atau peneliti mengkaji dan mempertimbangkan secara mendalam tentang hasil atau dampak dari tindakan yang dilaksanakan itu dengan mendasarkan pada berbagai kriteria yang telah dibuat. Berdasarkan hasil refleksi ini, guru dapat melakukan perbaikan terhadap rencana awal yang telah dibuatnya jika masih terdapat kekurangan sehingga belum memberikan dampak pernaikan dan peningkatan yang meyakinkan.

\section{Analisis Data}

Pengolahan data dilakukan selama penelitian dari awal sampai akhir. Langkah-langkah pengolahan data yaitu penyeleksian data dan mengolah data akurat yang dapat menjawab fokus penelitian. Data-data yang dikumpulkan selanjutnya disajikan dalam bentuk tabulasi data berupa tabel, diagram, dan grafik dengan tujuan untuk memudahkan dalam membaca data. Keberhasilan tujuan dapat ditentukan dengan cara analisis tes atau evaluasi. Teknik analisis data yang digunakan yaitu analisis data kualitatif dan kuantitatif. Analisis data kualitatif dengan menggunakan presentase sedangkan analisis kuantitatif dengan cara mencari nilai dan variasi. Adapun kriteria keberhasilan yaitu sebagai berikut :

\section{Teknik Penilaian}

Nilai rata-rata

$x=\frac{\sum(n x s)}{n}$

\section{Keterangan:}

$x \quad=$ Rata-rata hitung

$n=$ Banyak sampel

$(n \times s) \quad=$ Hasil perkalian skor dengan frekuensi skor yang bersangkutan

Persentase

$$
\begin{array}{r}
\text { Persentase }=\frac{\text { Jumlah siswa yang Tuntas }}{} \times 100 \% \\
\text { Jumlah banyaknya siswa }
\end{array}
$$


Nilai Akhir

$$
\begin{gathered}
\sum=\frac{N 1+N 2+N 3+N 4+N 5}{\sum \text { skor } \max } \\
\mathrm{x} 100 \%
\end{gathered}
$$

2. Rubik Penilaian

Tabel 3.2

Rubik Penilaian Keterampilan Renang Gaya Dada

\begin{tabular}{|l|l|c|}
\hline \multicolumn{1}{|c|}{ Indikator } & \multicolumn{1}{|c|}{ Keterampilan Yang Dinilai } & Skor Max \\
\hline Melakukan keterampilan & N1. Posisi tubuh & 5 \\
renang gaya dada dengan & N2. Posisi Kaki & 5 \\
baik dan benar & N3. Posisi Lengan & 5 \\
& N4. Posisi Napas & 5 \\
& N5. Koordinasi & 5 \\
\hline \multicolumn{2}{|l}{ Jumlah } & 25 \\
\hline
\end{tabular}

Tabel 3.3

Kriteria Nilai Pembelajaran Renang Gaya Dada

\begin{tabular}{|c|l|c|}
\hline Jenis Keterampilan & \multicolumn{1}{|c|}{ Kriteria } & Skor \\
\hline Posisi tubuh & $\begin{array}{l}\text { Sebagian besar kepala barada di bawah } \\
\text { permukaan air dan posisi bahu dan pinggul } \\
\text { sedikit berada di permukaan air (streamline) }\end{array}$ & 5 \\
\hline Posisi kaki & $\begin{array}{l}\text { Seluruh kaki bergerak disaat melakukan } \\
\text { gerakan sehingga kaki membentuk huruf "V", } \\
\text { namun pada saat meluncur kedua kaki dalam } \\
\text { keadaan lurus termasuk telapak kaki. }\end{array}$ & 5 \\
\hline Posisi lengan & $\begin{array}{l}\text { Gerakan lengan seperti sedang mendayung } \\
\text { dengan manarik lengan secara perlahan dari } \\
\text { atas menuju dada dan kembali lurus sambil } \\
\text { menyapu air agar menghasilkan gerakan maju. }\end{array}$ & 5 \\
\hline Napas & $\begin{array}{l}\text { Pada saat pengambilan napas, posisi badan } \\
\text { tidak naik hanya kepala saja yang sedikit } \\
\text { keluar dari permukaan air untuk mengambil } \\
\text { napas. }\end{array}$ & 5 \\
\hline $\begin{array}{l}\text { Gerakan lengan dan gerakan kaki dilakukan } \\
\text { secara beriringan. Dimulai dari meluncur } \\
\text { dimana lengan dan kaki dalam keadaan lurus, } \\
\text { kemudian ayunkan lengan sampai pada } \\
\text { pertengahan ayunan, lalu rekaveri dimulai, } \\
\text { pada saat kaki melakukan tendangan maka } \\
\text { lengan melakukan rekaveri, pengambilan } \\
\text { napas dilakukan pada saat lengan berada } \\
\text { didepan dada, gerakan seimbang dan berirama } \\
\text { antara kaki, lengan, dan napas. }\end{array}$ & 5 \\
\hline Koordinasi
\end{tabular}


Tabel 3.4

Kriteria Skor

\begin{tabular}{|c|c|}
\hline Skor & Keterangan \\
\hline 5 & Baik Sekali (BS) \\
4 & Baik (B) \\
3 & Cukup (C) \\
2 & Kurang (K) \\
1 & Kurang Sekali (KS) \\
\hline
\end{tabular}

\section{Cara Pengambilan Data}

1. Data mengenai keterampilan renang gaya dada didapatkan dengan cara melakukan observasi secara langsung, tes, dan catatan lapangan.

2. Data mengenai situasi belajar mengajar diliat dan diambil dengan menggunakan lembar observasi.

3. Data tentang refleksi perubahan serta perbaikan yang harus diberikan pada pembelajaran diambil dari catatan lapangan.

4. Data dokumentasi diambil pada saat proses belajar pembelajaran renang berlangsung.

\section{HASIL DAN PEMBAHASAN}

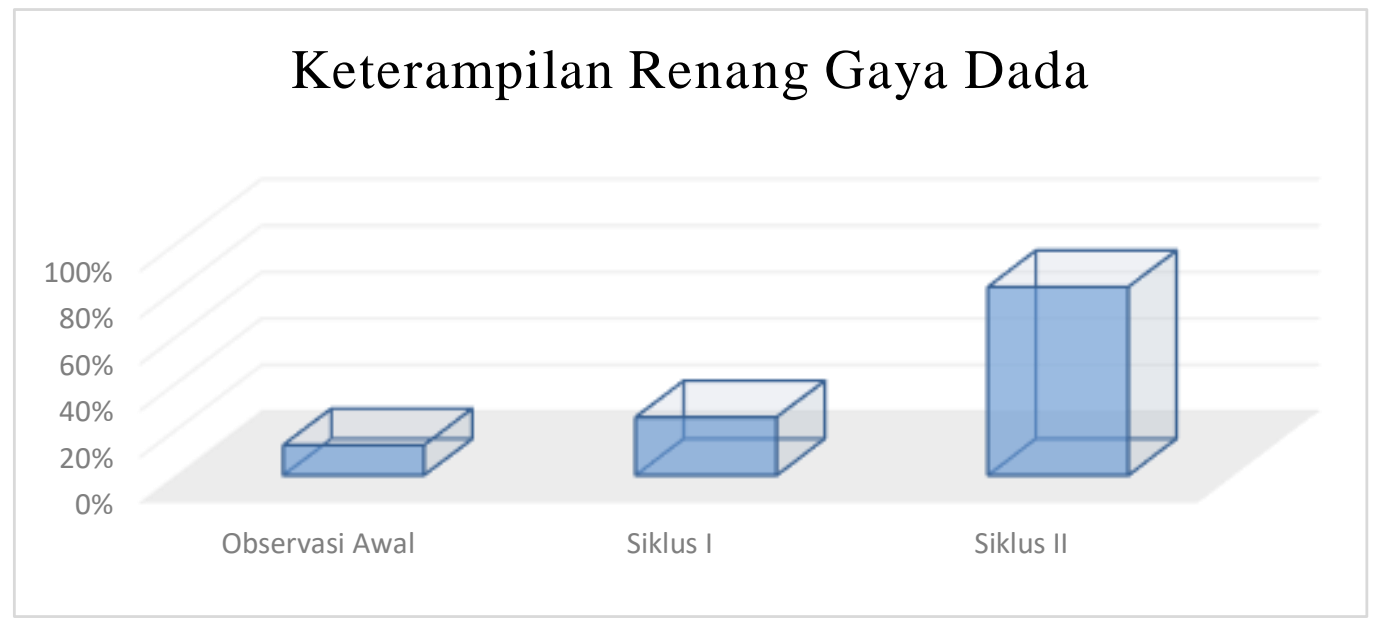

\section{Diagram 4.1}

Peningkatan Rata-rata Hasil Belajar Renang Gaya Dada

Berdasarkan dari data diagram diatas dapat dilihat bahwa peningkatan hasil belajar renang gaya dada dengan penggunaan model pembelajaran tutor sebaya dari siklus ke siklus terdapat peningkatan yang signifikan. Untuk hasil belajar pra siklus (kondisi awal) didapatkan hasil penguasaan keterampilan siswa dengan rata-rata nilai evaluasi adalah 43, nilai tertinggi 76, nilai terendah 24 dan presentase ketuntasan pada pra siklus yaitu $13 \%$, hal ini terjadi karena masih banyak siswa yang tidak memperhatikan penjelasan tentang renang gaya dada yang disampaikan oleh peneliti. Mereka lebih 
senang bermain-main air dengan teman-temanya yang lain dan ada juga yang masih merasa takut maupun malu untuk melakukan keterampilan gerak renang gaya dada.

Kemudian pada siklus I dilakukan kembali tes penguasaan keterampilan renang gaya dada dengan rata-rata nilai evaluasi adalah 64 dengan nilai tertinggi 92 nilai terendah 44 dan presentase ketuntasan pada siklus I yaitu $25 \%$. Dari pra siklus ke siklus I terlihat adanya peningkatan, hal ini terjadi karena siswa sudah di berikan latihan keterampilan renang gaya dada dengan menggunakan alat bantu ban karet. Pada siklus II tes penguasaan keterampilan siswa meningkat dengan baik, dengan rata-rata nilai evaluasi 78 , nilai tertinggi 100, nilai terendah 52 dan presentase ketuntasan siswa pada siklus II yaitu $81 \%$. Ini artinya pada setiap tindakan dari observasi awal sampai pada siklus II terdapat peningkatan yang signifikan. Sedangkan untuk pencapaian ketuntasan dalam hasil belajar renang gaya dada siswa pada observasi awal adalah $13 \%$ atau hanya 4 orang siswa yang mampu mencapai nilai KKM yang telah ditentukan. Kemudian pada siklus I pencapaian ketuntasan yang diperoleh siswa adalah $25 \%$ atau 8 orang siswa yang mampu mencapai nilai KKM. Dan terakhir pada pelaksanaan tes siklus II pencapaian ketuntasan sebesar $81 \%$ atau 27 orang siswa dari jumlah 32 telah mampu untuk mencapai nilai KKM.

Berdasarkan hasil dari data yang diperoleh di siklus pertama, ketuntasan dalam pembelajaran renang gaya dada pada siswa yaitu mencapai $25 \%$, ini artinya terdapat peningkatan dari hasil observasi awal yang sebesar 9\%. Data tersebut menunjukkan bahwa 8 siswa dari 32 siswa telah mencapai nilai KKM yang ditentukan. Dari data diatas,terlihat bahwa hasil evaluasi akhir dari siklus I mengalami peningkatan yang cukup baik, namun peneliti mempunyai anggapan bahwa masih terdapat kekurangan dalam penguasaan materi. Oleh karena itu peneliti memutuskan untuk melakukan perencanaan dan pelaksanakan tindakan berikutnya menuju siklus II. Sedangkan hasil data dari siklus II tindakan II menunjukkan bahwa adanya peningkatan yang cukup signifikan. Hasil peningkatan ketuntasan belajar dari siklus I sampai ke siklus II mencapai 59\%, dari $22 \%$ ke $81 \%$. Ini berarti kebanyakan siswa telah mencapai nilai KKM yang telah ditentukan, walaupun masih ada beberapa siswa yang masih belum mampu mencapai niali tersebut. Namun secara keseluruahn proses pembelajaran keterampilan renang gaya dada dengan menggunakan alat bantu ban karet ini dapat dinyatakan sukses dengan melihat peningkatan yang terjadi pada siswa.

Hal ini menunjukkan bahwa peran guru dalam memberikan pembelajaran yang variatif sangat berpengaruh terhadap perkembangan pemahaman siswa (Probo Yusuf Wicaksono, 2017). Dengan metode dan cara belajar yang mudah dipahami oleh siswa akan berdampak positif dan siswa akan lebih termotivasi untuk belajar. Model pembelajaran Peer Teaching mempunyai ciri khas yang unik, di mana yang akan mengajar atau mengantikan guru dalam memberikan suatu materi, yaitu seorang siswi yang memiliki pengetahuan atau skill yang lebih baik dari teman kelasnya (Mirzeoğlu, 2014). Peer Teaching kondusif untuk mempromosikan lingkungan belajar yang positif dan menarik bagi tutor maupun learner. Dampak yang jelas dari implementasi dari Peer Teaching adalah pengembangan kognitif, psikososial dan keterampilan motorik (Nasution, 2017). Maka peneliti menyimpulkan bahwa hasil penelitian ini selaras dengan penelitian sebelumnya yang menunjukan bahwa penggunaan model pembelajaran tutor sebaya memberikan pengaruh yang signifikan terhadap hasil belajar renang gaya dada siswa sekolah dasar.

\section{KESIMPULAN DAN SARAN}

Berdasarkan hasil analisis dan pengolahan data pada penelitian yang telah dilaksanakan di SDN 195 ISOLA, maka dapat ditarik kesimpulan bahwa melalui penggunaan model pembelajaran tutor sebaya memberikan pengaruh yang signifikan terhadap hasil belajar siswa dalam pembelajaran renang gaya dada di sekolah dasar. Hal ini terbukti dari hasil tes setiap siklus nya, keterampilan dan pemahaman siswa mengenai pembelajaran tersebut semakin berkembang dan meningkat dengan 
baik. Sehingga dengan adanya peningkatan tersebut, banyak siswa yang sebelumnya memiliki nilai yang kurang telah bisa mencapai KKM dengan nilai yang cukup memuaskan. Selain itu, siswa pun terlihat lebih aktif selama proses pembelajaran berlangsung. Dengan begitu dapat dinyatakan bahwa model pembelajaran tutor sebaya memberikan pengaruh yang signifikan terhadap hasil belajar siswa dalam pembelajarn renang gaya dada di sekolah dasar.

\section{DAFTAR PUSTAKA}

Arikunto, Suharsimi. (2006). Prosedur Penelitian (edisi revisi VI). Jakarta: Rineka Cipta.

Arjanggi, R., \& Suprihatin, T. (2010). Metode Pembelajaran Tutor Teman Sebaya Meningkatkan Hasil Belajar Berdasar Regulasi-Diri. Makara Human Behavior Studies in Asia, 14(2), 91-97. https://doi.org/10.7454/mssh.v14i2.666.

Casey, A., \& Quennerstedt, M. (2020). Cooperative Learning in Physical Education Encountering Dewey' s Educational Theory, 26(4), 1023-1037. https://doi.org/10.1177/1356336X20904075

Chróinín, D. N., Fletcher, T., Sullivan, M. O., Ní, D., Fletcher, T., \& Pedagogical, M. O. S. (2018). Pedagogical Principles of Learning to Teach Meaningful Physical Education, 8989. https://doi.org/10.1080/17408989.2017.1342789

Elia, F. D. (2020). Teachers ' Perspectives About Contents and Learning Aim of Physical Education in Italian Primary School, 15(April), 279-288. https://doi.org/10.14198/jhse.2020.15.Proc2.19

Erdo, R. (2021). Determination of Physical Education and Sports Teachers' Nutrition Habits and Physical Activity Levels in the Global Epidemic (Covid-19) Process, 7(1), 51-59. https://doi.org/10.20448/journal.522.2021.71.51.59

Jatmika, H. M., Hariono, A., Purwanto, J., \& Setiawan, C. (2017). Analisis Kebutuhan Guru Pendidikan Jasmani , Olahraga dan Kesehatan Pasca Program Guru Pembelajar Needs Analysis For The Sport and Health Education Teachers After The Implementation Of Learning - Teacher Program, 12(1), 1-11.

Jiwa, I. K. (2019). Penerapan Metode Belajar Part and Whole Untuk Meningkatkan Hasil Belajar Penjaskes Materi Senam Lantai ( Lompat Kangkang ), 2(1), 65-71.

Lekarskie, W., Oryginalna, P., Opanasiuk, F. H., Griban, G. P., Yahodzinskyi, V. P., Mozolev, O. M., $\&$ Prontenko, K. V. (2020). CHECKING OF THE METHODICAL SYSTEM EFFICIENCY OF FITNESS TECHNOLOGIES APPLICATION IN STUDENTS' PHYSICAL EDUCATION, (2). https://doi.org/10.36740/WLek202002125

Mirzeoğlu, A. D. (2014). The Effects of Peer Teaching On The University Students ' Achievements In Cognitive, Affective , Psychomotor Domains And Game Performances In Volleyball Courses, 9(9), 262-271. https://doi.org/10.5897/ERR2013.1690

Nasution, M. K. (2017). Penggunaan Metode Pembelajaran Dalam Peningkatan Hasil Belajar Siswa, 11(1), 9-16.

Pawlowski, C. S., \& Skovgaard, T. (2020). Physical activity in the classroom : Using RE-AIM to Evaluate A National School Reform - A Mixed Methods Study, 1-20.

Probo Yusuf Wicaksono, J. B. P. (2017). PERAN GURU PENDIDIKAN JASMANI OLAHRAGA DAN KESEHATAN TERHADAP PENDIDIKAN KESEHATAN DI SMA DAN MA SEKECAMATAN SOOKO Probo Yusuf Wicaksono Junaidi Budi Prihanto Abstrak, 05, 92-97.

Renno Adiesta, A. R. S. T. (2017). Renno Adiesta Abdul Rachman Syam Tuasikal ISSN : 2338-798X, 483-489.

Ruiz-montero, P. J., Chiva-bartoll, O., \& Salvador-garc, C. (2019). Learning With Older Adults Through Intergenerational Service Learning In Physical Education Teacher Education.

Setiawan, A., Yudiana, Y., Ugelta, S., Oktriani, S., \& Budi, D. R. (2020). Journal of Teaching Physical Education in Elementary School Hasil Belajar Pendidikan Jasmani dan Olahraga Siswa Sekolah 
Dasar : Pengaruh Keterampilan Motorik ( Tinggi ) dan Model Pembelajaran (Kooperatif), 3(28), $59-65$.

Toan, P. D. (2020). Current State Of Teaching And Learning Basketball For Non - Physical Education Major Students Of Bac NINH Sports University, 7(4), 20-23.

Widagdo, A. K. (2010). Hasil Pembelajaran Dengan Metode Konvensioanal Dan Metode Tutor Sebaya Terhadap Peningkatan Teknik Passing Sepak Bola Pada Kelas Viii Smp N 1 Kesesi Kabupaten Pekalongan Tahun Ajaran 2009/2010.

Wilke, J., Fleckenstein, J., Krause, F., \& Vogt, L. (2016). Sport - Specific Functional Movement Can Simulate Aspects Of Neuromuscular Fatigue Occurring In Team Sports, 3141(April). https://doi.org/10.1080/14763141.2016.1159322

Wiriaatmadja, Rochiati. 2008. Metode Penelitian Tindakan Kelas Untuk Meningkatkan Kinerja Guru Dan Dosen. Bandung: PT Remaja Rosdakarya. 